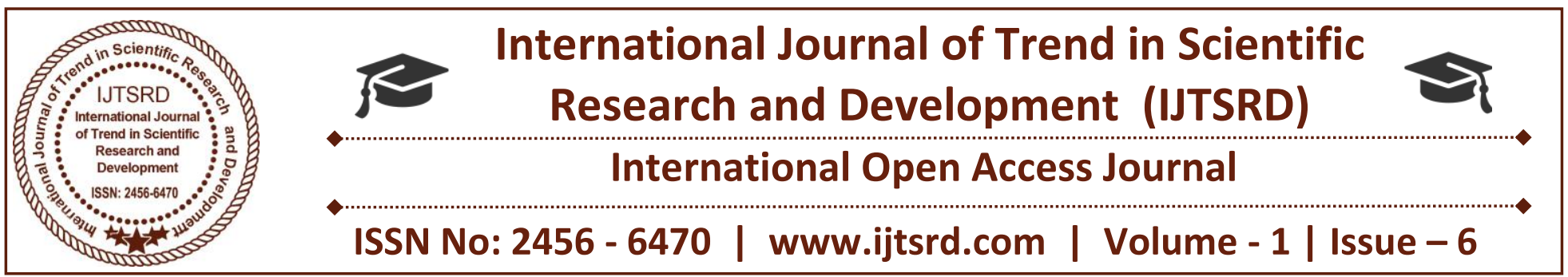

\title{
The Assessment of Effects of Migration and Remittanceson Nigerian Economy
}

\author{
Ogwuru, H. O. R, \\ Department of Economics, Abia State University, \\ Uturu, Nigeria
}

\author{
Uma, K. E, \\ Department of Economics \& Development Studies, \\ Federal University Ndufu Alike Ikwo, Nigeria
}

\section{ABSTRACT}

The study focuses on the examination of the influence of migration and remittances on Nigerian economy over the years. The authors reviewed and examined the positive and negative effects of migration in Nigeria. Expository approach involving tables were employed in the examination. The study confirmed the fact that there are positive and negative effects of migration in Nigeria but asserted that the negative effects outweigh the positive in view of the large proportion of Nigerian quality human capital outside Nigeria and also the large proportion of migrants in Nigeria who also remit a large proportion of their income to their home economies. It was also inferred from the study that if adequate working condition and environment exist and Nigerians migrants return, their contribution would have greater effect on the economy than mere remittances. On this basis the authors made the following recommendations among others:revamping both the rural and urban environment, restructuring social amenities; upgrading and maintenance of infrastructural requirement of the society; insecurity and frequent crisis such as group agitations, religious disharmony, crimes, Boko Haram insurgence among others must be addressed; condition of service for all categories of workers at the local, state and federal levels need to be urgently harmonized; good atmosphere for operation cum the materials required by the academics, doctors, nurses, lawyers, architects, economists among others must be provided to enable them put in their best.
Keywords: Assessment, effects, economy, migration, remittances

\section{INTRODUCTION}

All over the world, there has been frequent movement of people from place to place. In recent times some move just for holidays, sight-seeing and experiencing climatic condition, cultural pattern and perception of life in other countries. Nevertheless, many people migrate to other areas and permanently settle to work or engage in any means of earning a living and occasionally visit home countries. United Nations (2009) points out that 215 million people which is 3 percent of the world population are residing in countries outside their countries of birth. Nigeria as a country is not left behind in the various motive of movement to other countries of the world. National Bureau of Statistics (2010) articulated that Nigeria is the most populous nation in Africa with a population estimate of 163 million and with a poverty level of $70 \%$. Prior to and since after independence many Nigerians have resorted to internal and external migration with the motive of seeking a better living environment and means of livelihood.

Some Nigerians especially the rich class often move to other countries just for visiting, sight-seeing, holiday, business, schooling, conferences, medication among others.Mohapatra et al (2010) points out that political problem, internal conflicts and trafficking are relevant causes of international movement, but out of 
ten persons, nine migrate due to economic reasons. There are many reasons attributed to frequent traveling and migration to other countries by Nigerians. The level of social facilities in Nigeria such as hospitals, education centres and the entire environments are below the demands and expectations of many Nigerians. In their study, Uma et al (2013) asserted that the occasional political, community clashes and religious upheavals in Nigeria have significantly compel urban-rural, rural-urban and international migration. In addition, the search for better income yielding ventures or white-collar jobs by school leavers, graduates, artisans and the desire to benefit from urban environment and social facilities that are deficient in the rural areas have contributed to incessant migration. In related view, Hughes and Kroechler (2008) articulated that migration originated from two relevant factors known as the push and pull factors. Dwellers in a place are motivated to leave an area due to the push factor while the fascinations to choose a place for settlement are referred to as the pull factor. There have been high tendency for people to opt to satisfy the push factor in Nigeria because of poor economic situation, poor environment, poor working condition, poor remuneration, low degree of application of the rule of law, insecurity, social vices amongst others. This is because the leaders of the country have not been able to effectively improve the economy in such a way as to have all that is required to promote living standard. The attention given to the institutions like schools, tertiary institutions and training centres have not been sufficient to encourage many Nigeriansto have trust on the quality of the products and as such prefer patronizing other countries, hence you see many Nigerians in Ghana, South Africa and European countries pursuing education. It has been reiterated that insecurity of life and property due to incessant insurgence, religious crisis and soon have compel many Nigerian to migrate to other countries. Besides, inability to industrialise has left abundance resources unemployed, thereby leaving idle land, raw materials, labour among others grossly underutilized.

Man as a rational and irrational being is always willing to respond to situations. Migration has become one of the ways taken by Nigerians to seek for unsatisfied circumstances in its domestic home. Rural dwellers are frequently moving to urban places searching for non-available better job opportunities, social facilities, training centres, good housing, medical centres among others. Both rural and urban dweller are also migrating to other countries of the world looking for better environment devoid of the harsh situations inherent in Nigeria for economic activity. Hence, you have Nigerians virtually in all parts of the world.

International Organization for Migration (2013) showed that the number of Nigerian migrants living outside Nigeria rose from 1.9 million in 2004 to 3.4 million in 2012. It was shown by UNHCR (2009) that the total number of Nigerians who sought for asylum in different foreign countries were respectively 19,407 in 2003, 10,464 in 2005, 10,148 in 2007 and 15,022 in 2008. In literature, various studies such as Rena (2008), United Nations Global Migration Group (2015), UN Department of Economic and Social Affairs (2012), Mahapatra et al (2010) .amongst others have articulated the beneficial and nonbeneficial effects of migration given its negative effect on developing economies with respect to loss of human capital or labour force and positive effect due to remittances. Many studies by authors such as Anyanwu and Erhijakpor (2010), Ajayi et al (2009), Gupta et al (2007), Adams and Page (2005), Lachaud (1999) and Adams (1991) have shown that remittances play significant role in reducing various types of poverty in developing countries and also encourage economic activity. This view of remittance is not applicable to all migrants. Study by Nwosu et al (2012) asserted that remittance vary significantly by the country of resident by the migrants and it also depends on the education level of migrant before migration, type of work engaged and macroeconomic condition in the migrant country of resident.

Undoubtedly, one important actions of theNigerian migrants who have properly settled is that they often remit money back home, help others to join them and support the education of relations and family members. Others also remit reasonable money for construction of houses and investment. They help in empowering people. The World Bank data showed that Nigeria had \$1, 392 billion remittances in 2001 and in 2011; it rose to $\$ 10.681$ billion which is a significant increase. It equally showed that remittance contributed 5\% to gross domestic product in 2011. But it is obvious that many migrants are professionals/experts in medicine, engineering, education, entrepreneurship, sciences and so on. These caliber of migrants usually leave with their expertise, capital, talents and ingenuity to settle in other regions of the world, thereby, denying a 
developing economy of the impact of such desirable role expected at home to support development efforts. Given the recent discourses on the positive and negative effects of migration and remittances, most studies focused only on either positive or negative aspect of either remittance or migration, but in this study, it is our intention to review migration vis-a-vis remittances in Nigeria with a view to proffer policy implications needed to regulate migrations and discourage brain-drain. In this respect, the paper is streamlined thus: section two is the review of literature, section three is an over-view of the effects of migration; an over-view of the effects of remittance is the section four while section five is the way forward and conclusion.

\section{REVIEW OF LITERATURE}

There have been series of issues, studies on migration and remittances over the years. Various studies support positive effects while others oppose to it. In this section, it is our intention to examine both theoretical and empirical literature. There is movement of factors of production from one region to the other due to migration. In his view Myrdal (1957) articulated the experience of less developed countries emanating from migration which involves chains of causes and effect that he likened to the vicious circle of poverty. The effects are referred to as backwash and spread effects. It presupposes that when people in underdeveloped nations migrate, they usually leave with their expertise (human capital), physical capital (tools, cash), goodwill among others. This action creates imbalance with respect to employment, decline of income and output usually produced by the migrants while at home. It is usually not easy to bring equivalent resources to replace all taken away by migrants. This contractionary effect impacts adversely to underdeveloped economy. This is the backwash effect which is the negative experience of a locality due to migration. On the contrary, the migrants settled at a place with all the factors of production and then contribute to output, income and employment of the resident economy which is spread effect. The expansionary effect of skilled migrants in an area has expansionary effect which remittance may not cover up the effects created at the home economy, if and only if the remittance is immediate but it is not. So, underdeveloped economic development is retarded by the extent to which its professional migrates.

Migration is perceived to originate from the push and pull factors (Hughes and Kroechler, 2008) It has been reiterated that the push factor which is the driving force for people to leave an area is stronger in underdeveloped nations due to bad governance, poor economic and social environment. Hence, you see incessant rural-urban movement and forceful desire to travel outside the country by Nigerians. This is a major cause of brain drain in Nigeria. This made Silva (2007) to pinpoint that regular brain drain syphon skill manpower of developing countries leading to loss of human capital at some costs such as training and education costs and loss of productivity which reduces the aggregate gross domestic product. Hence, brain drain is viewed as international transfer of productive inputs in form of human capital lacking in a region which is not accounted for in the balance of payment statistics. This is reflected in UNTAC estimate that highly trained African migrants age between 25-35 who usually travel abroad has a monetary value of \$184, 000 at 1997 price (Rena, 2008; Kartz, 2000)

In their study, Funk et al ( 2017) posit that the level of migration and asylum seekers have raised the burden on migrant countries and so compelled European Union's interest in tackling the root cause and strengthening third world nations migration management efforts through improved cooperation in order to lower the influx. This new intention is based on the ground that increased development aid in the less developed economies will lessen the inclination to migrate to other countries. This has also lead to adoption of cooperative efforts regarding border control and readmission; hence development support of European Union (EU) is now linked to cooperation with respect to migration management. The issue is that there is a shift of articulated European Union Treaties from primary objective of poverty alleviation which may counter economic interest of third countries. There is this believe by EU that increased development of third nations will reduce migration but it may not be so. However, European Union has adopted new approach perceived to be more rewarding which include work/visa scheme, trade agreements or lessening remittance cost; increased support on governance aid considered as a more effective means of lowering migration and putting in place more legal channels for migration so as to constrain those illegal business.

Knoll and Sherriff (2017) in their study were concerned about the rising population of refugees and migrants seeking for protection in Europe due crisis 
and wars, clashes, disorder, poverty in Syria, Middle East and Africa disagreements which brought some pressure in Europe. Hence, European states are concerned with battling with this problem outside Europe through cooperation with non-European countries. This led to revamping of level of aids and European Development policy priorities in order to surmount the new trend of influx of people from other parts of the world. The case study focused on the aid responses by five countries which are: Denmark, the European Union institutions, Germany, the Netherlands and Sweden. And also the effect of changes in policy frameworks, strategies, tools, allocation yardstick and practices of programme would impact on the use of Official Development Assistance (ODA). The national budget have shown higher reallocation to meet with the cost situations and reduction in long term development aids earmarked for supporting and development of other countries..Earlier study of microanalysis of migration recounted various motives while migrant workers send money back home. For instance Lucas and Stark (1985) study in Botswana asserted that the two motivations to send money back home are pure selflessness and outright self-interest. The latter is mainly to acquire durable assets such as land, housing and other personal interests while the former is strictly to improve the lives of family members, relations and friends. In each aspect of the two areas migrants remit money, it is because he can afford it and knows the poor living status of those left behind at domestic economy.

Other authors such as Higgins et al (2004), El-Sakka and McNabb (1999), Straubhaar (1986) see remittance to be influenced by variation of macroeconomic variable such as interest rate in domestic economy vis a vis resident of migrant workers. Exchange rate has greatly influence remittance in Nigeria. For instance at moment in Nigeria in which exchange rate is over three hundred and twenty naira ( $\$ 320$ ) per dollar, migrant workers remittances, besides helping family members do have a large amount of naira after exchange foreign for investment and acquisition of costly land property in any part of the country. It has been confirmed by a study of Egypt by El-Sakka and McNoabb (1999) that these two macroeconomic variables exchange rate and interest rate differentials play significant role in the desire and motivation to remit through official channels.

In spite of the views of that remittance inflows impacts positively on economic growth, but empirical findings from Singh et al (2009), Barajas et al (2009), World Bank (2006), Spatafora(2005), IMF, 2005, contradict this view as only little evidence was found. Various views have been articulated about the effects of remittance on one economy or the other such as lowering of work efforts on the part of households who receive remittance and consequently lessen longrun growth (Azam and Gubert, 2006; Chami et al, 2003); stimulate growth because of its improvement of financial access and financial development (Gupta et al 2007; Toxopeus and Lensik, 2007); raising income level of the poor subsection of the economy and not necessarily the growth of the entire economy amongst others. However, Mahapatra et al (2010) posit that still there is inconclusive outcome of effect of remittance on growth mainly because of the difficulty of separating the cause from the effect. Many individual would not have left home economy if not some causative factors like natural disaster, war, political turmoil and so on to other nations of the world.

\section{AN OVER-VIEW OF THE EFFECTS OF MIGRATION}

The increased migration in Nigeria has impacted in different ways to the development of Nigeria economy. The level of Nigerian experts in other country of the world is a thing to worry about. How many Americans are in Nigeria? This means that there is something happening in the countries that are detested by Nigerians. The table below shows the Nigerian migrants outside Africa.

Table 1: Estimate of Nigerians Living outside Africa 1989-2004

\begin{tabular}{|l|l|l|}
\hline Country & Year & Population \\
\hline Italy & 1989 & 3,575 \\
\hline France & 1999 & 1,425 \\
\hline UK & 2001 & 88,380 \\
\hline Canada & 2001 & 10,425 \\
\hline Austria & 2001 & 2,913 \\
\hline Australia & 2001 & 1,783 \\
\hline Greece & 2001 & 2,021 \\
\hline Ireland & 2002 & 9,225 \\
\hline Germany & 2002 & 16,183 \\
\hline Netherlands & 2003 & 4,564 \\
\hline Belgium & 2004 & 1,636 \\
\hline US & 2004 & 160,000 \\
\hline Total & & $\mathbf{3 0 2}, \mathbf{1 3 0}$ \\
\hline Sources: & OECD & 2006 \\
\hline
\end{tabular}

http://www.migrationinformation.org 
Just as many Nigerians are resident outside Africa, so many are in countries within Africa. Some Nigerians outside are illegal migrants and their number not included in the above information. Nevertheless, a large proportion of Nigerians are desperately yearning to leave the country. This situation has created a vacuum which remittance may not cover up. Many of these Nigerian are highly educated and experts in their field of studies. Disgustingly, the incessant industrial actions or trade disputes, especially in the social and economic sector where education falls has witnessed highest level of industrial strike. Since 1970s there have been series of trade disputes due to one agitation or the other. Central Bank of Nigeria (1998) states that out of 199 trade disputes in 1994, involving 1, 541,146 workers led to loss of man-days of 234, 307, 748. Many Nigerians' bright minds resort to leaving the country at those periods. Our leaders have not learnt from this situation and have allowed the recurring of industrial disputes. In recent time, the Academic Staff of Universities Union (ASUU) embarked on strike due to inability of the federal government of Nigeria to keep and fulfil agreements. This was followed by the Resident Doctors trade dispute, leading to the collapse of medical and health institutions. The environmental situation of workers, lack of infrastructure for performance and coupled with poor condition of service have always compel many professional to migrate out of the country. The gains of migration in consideration of the remittances cannot be whole regarded as being the best for a developing economy. The level of gross domestic product is lessened by migration of productive labour. This means to minimize migration, Nigeria has to adopt and borrow a leaf from those countries settled by Nigerians

Table 2 Showing Nigerian emigrants' major countries of destination 2010 \& 2013

\begin{tabular}{|c|c|c|c|c|c|c|}
\hline \multirow{2}{*}{$\begin{array}{c}\text { Countries of } \\
\text { Destination }\end{array}$} & Male & Female & Total & Male & Female & Total \\
\cline { 2 - 6 } & & & & & & \\
\hline Benin & 22,691 & 14,345 & 38,036 & 26,680 & 15,895 & 42,575 \\
\hline Burkina Faso & 1,662 & 1,898 & 3,560 & 1,719 & 1,963 & 3,682 \\
\hline Cameroon & 66,628 & 47,923 & 114,551 & 67,529 & 48,092 & 115,621 \\
\hline Canada & 8,877 & 9,683 & 18,560 & 9,231 & 10,094 & 19,325 \\
\hline Cote d' Ivoire & 21,566 & 20,863 & 42,429 & 22,363 & 21,398 & 43,761 \\
\hline Finland & 1,192 & 258 & 1,450 & 1,509 & 335 & 1,844 \\
\hline Gabon & 14,866 & 5,368 & 20,234 & 16,798 & 5,981 & 22,779 \\
\hline Ghana & 17,190 & 13,222 & 30,412 & 18,385 & 13,995 & 32,380 \\
\hline Germany & 16,146 & 6,285 & 22,431 & 16,297 & 6,390 & 22,687 \\
\hline Greece & 2,719 & 1,083 & 3,802 & 2,798 & 1,137 & 3,935 \\
\hline Ireland & 5,959 & 7,595 & 13,554 & 7,951 & 10,589 & 18,540 \\
\hline Italy & 13,611 & 21,486 & 35,097 & 21,154 & 26,919 & 48,073 \\
\hline Netherland & 3,607 & 2,745 & 6,352 & 3,898 & 3,104 & 7,002 \\
\hline Niger & 10,153 & 9,569 & 19,722 & 10,315 & 9,747 & 20,062 \\
\hline Saudi Arabia & 8,962 & 4,695 & 13,657 & 9,745 & 4,933 & 14,678 \\
\hline South Africa & 13,043 & 2,884 & 15,927 & 15,249 & 3,410 & 18,659 \\
\hline Spain & 22,291 & 13,968 & 36,259 & 21,976 & 14,909 & 36,885 \\
\hline Sudan & 8,364 & 7,850 & 16,214 & 7,886 & 7,389 & 15,275 \\
\hline Sweden & 2,106 & 891 & 2,997 & 2,461 & 1,176 & 3,637 \\
\hline Switzerland & 2,138 & 835 & 3,073 & 2,367 & 1,084 & 3,451 \\
\hline Togo & 8,958 & 7,082 & 16,040 & 9,046 & 7,137 & 16,183 \\
\hline UK\&N Ireland & 72,498 & 75,961 & 148,459 & 89,193 & 95,121 & 184,314 \\
\hline USA & 136,420 & 106,932 & 243,352 & 141,364 & 110,808 & 252,172 \\
\hline & & & & & & \\
\hline & & & & & & \\
\hline & & & & & & \\
\hline
\end{tabular}

Nigerian migrants have chosen both African and nonAfrican countries as places of settlement. Total migrants outside Nigeria are so many and the accurate figure yet to be arrived at because of illegal migrants who cannot easily make their biodata available.
However, International Organisation for Migration (IOM, 2009) migration profile and World Bank (2010) report on Nigeria remittance pointed that Nigerian emigrants' total number ranges between 836 , 832 and 1, 041, 284. In some nations female migrants 
out-number male and vise-versa. The dominant countries Nigerian migrants reside in 2010 and 2013 respectively are USA $(243,352 ; 252,172)$ and UK \& North Ireland $(148,459 ; 184,314)$, in each, female are more in population while in Africa the concentration of Nigeria in Cameroon in 2013, stood at 115,621 , followed by Cote d' Ivoire with Nigerian migrants of 43, 761. Virtually every country of the world has a Nigerian living in it. Notwithstanding the high population of Nigerians in other countries, many Nigerian are still eager to leave. However, it is obvious from the table that total male population migrants outside the country are higher than the female and there has been regular increase of migrants every year.

\section{Migrant strategy through Asylum Seeking}

Just with the desire to leave Nigeria, many have decided to sake for shelter and safety in other countries of the world when Nigeria is not witnessing any civil war. Table 2 shows the different nations Nigerians have sought for settlement over the years.

Table 3 Showing Nigerian Asylum-seekers in Various Countries, 2000-2008

\begin{tabular}{|c|c|c|c|c|c|c|c|c|c|}
\hline Country & 2000 & 2001 & 2002 & 2003 & 2004 & 2005 & 2006 & 2007 & 2008 \\
\hline Australia & 390 & 1,047 & 1,432 & 1,849 & 1,828 & 880 & 421 & 394 & 535 \\
\hline Canada & 800 & 790 & 828 & 637 & 589 & 591 & 685 & 760 & 765 \\
\hline France & 463 & 571 & 884 & 1,252 & 1,572 & 976 & 434 & 446 & 462 \\
\hline Germany & 420 & 526 & 987 & 1,051 & 1,130 & 608 & 481 & 503 & 561 \\
\hline Greece & 14 & 33 & 184 & 444 & 325 & 406 & 391 & 390 & 746 \\
\hline Ireland & 3,405 & 3,351 & 4,050 & 3,110 & 1,776 & 1,278 & 1,038 & 1,028 & 1,009 \\
\hline Italy & 47 & 388 & 594 & 722 & 930 & 536 & 0 & 1,336 & 5,673 \\
\hline $\begin{array}{l}\text { South } \\
\text { Africa }\end{array}$ & 114 & 223 & 3,244 & 4,550 & 1,058 & 775 & 712 & 904 & 16 \\
\hline Spain & 843 & 1,350 & 1,440 & 1,688 & 1,029 & 726 & 632 & 680 & 808 \\
\hline Switzerland & 226 & 289 & 1,062 & 480 & 418 & 219 & 209 & 310 & 988 \\
\hline $\begin{array}{c}\text { United } \\
\text { Kingdom }\end{array}$ & 835 & 870 & 1,125 & 1,110 & 1,210 & 1,230 & 940 & 905 & 970 \\
\hline $\begin{array}{l}\text { United } \\
\text { States }\end{array}$ & 58 & 50 & 73 & 99 & 82 & 59 & 162 & 165 & 177 \\
\hline Others & 1,207 & 1,638 & 2,249 & 2,415 & 2,326 & 2,180 & 2,189 & 2,327 & 2,312 \\
\hline Total & $\mathbf{8 , 8 3 2}$ & 11,236 & 18,152 & 19,407 & 14,273 & 10,464 & 8,294 & 10,148 & 15,022 \\
\hline
\end{tabular}

Source: UNHCR (2009).

From the above table, the topmost countries, Nigerian citizens have sought for asylum is in Ireland, United Kingdom, Canada, Spain and Italy. From 2000-2008 was relatively calm in Nigeria as it was devoid of civil war except occasional political crisis, boundary disputes, Niger Delta Militia disturbances, religious crisis/Boko Haram insurgency in the north, kidnapping and armed robbery among others. The data show high degree of dissatisfaction of many citizens living in Nigeria. Besides, the level of insecurity of life and property, and high level of unemployment given the fact that Nigeria has not developed industries capable of engaging job seekers and also there is no policy on birth control. The high rate of population growth rate is not supported with social facilities, infrastructure and employment opportunities that can absorb school leavers.

Furthermore, the disregard of agriculture and imbalance in the economy in respect of the rural and urban areas environmental disposition have continuously push rural inhabitants to look for greener pasture either in the urban or outside the country. Consequently, many Nigerian are willing to migrate to other countries in any way possible, be it legal or illegal. 
International Journal of Trend in Scientific Research and Development (IJTSRD) ISSN: 2456-6470

Table 4 Showing Nigerian Refugees in Countries of Resident 2009-2013

\begin{tabular}{|c|c|c|c|c|c|}
\hline Countries & $\mathbf{2 0 0 9}$ & $\mathbf{2 0 1 0}$ & $\mathbf{2 0 1 1}$ & $\mathbf{2 0 1 2}$ & $\mathbf{2 0 1 3}$ \\
\hline Australia & 88 & 101 & 106 & 116 & 132 \\
\hline Austria & 173 & 228 & 288 & 315 & 346 \\
\hline Cameroon & 2,873 & 2,873 & 3,223 & 3,223 & 7,459 \\
\hline Canada & 2,962 & 2,873 & 3,608 & 3,990 & 4,441 \\
\hline France & 658 & 726 & 794 & 889 & 988 \\
\hline Germany & 2,640 & 2,601 & 2,667 & 2,833 & 720 \\
\hline Ireland & 766 & 777 & 706 & 540 & 477 \\
\hline Italy & 2,154 & 2,200 & 2,369 & 2,964 & 4,638 \\
\hline Netherlands & 205 & 203 & 216 & 213 & 225 \\
\hline Niger & - & - & - & - & 8,385 \\
\hline Norway & 46 & 65 & 93 & 109 & 176 \\
\hline Sweden & 93 & 124 & 147 & 178 & 257 \\
\hline Switzerland & 61 & 66 & 83 & 92 & 113 \\
\hline United Kingdom & 1,370 & 1,044 & 1,089 & 1,166 & 1,244 \\
\hline United States & 809 & 719 & 686 & 719 & 733 \\
\hline Others & 681 & 742 & 1066 & 674 & 1,280 \\
\hline Total & $\mathbf{1 5 , 6 0 9}$ & $\mathbf{1 5 , 6 4 0}$ & $\mathbf{1 7 , 1 4 1}$ & $\mathbf{1 8 , 0 2 6}$ & $\mathbf{3 1 , 6 1 4}$ \\
\hline
\end{tabular}

Sources UNHCR (2014); SIHMA (2014)

Nigerians at different period have sought for settlement in various countries of the world. These include both skilled and unskilled. The increase has been conspicuous in Cameroon, Canada, Italy, and United Kingdom. The highest and most recent is in Niger because of the incessant insurgence in the northern part of Nigeria. Few of the countries have a common boundary with Nigeria and as such very easy for Nigerians to cross over. In addition to this, it can be inferred that there are Nigerians in each of the country not captured in the data. One wonders why this regular migration to other countries of the world. The reasons are not far-fetched because the on-going crisis in Nigeria since over five years ago has stimulated many Nigerian to look for a serene and better living condition outside the country. It can equally be seen from the angle of high cost of doing business and high level of corruption in the country has lessen peoples' confidence in living in the country and as such many prefer to seek for shelter in other counties. It can equally be pointed that serious and unabated revamping of the conditions of Nigerians is yet to commence in spite of good policies. High income inequality as seen in the income of senators in Nigeria vis-à-vis other Nigerian workers who obtain same goods in same market is really worrisome. Quite disheartening is that many Nigerians such as teachers and other artisan affected by irregular power supply are willing to accept menial jobs in neighboring countries and European countries if given any slight opportunity. The absence of over 97, 000 people categorised as refugees lessen the gross domestic product given the fact that even if remittance is done, it cannot be commensurate with their contributions in Nigeria.

\section{Immigrants in Nigeria}

Nigeria has at different periods harbor people from other countries. The total number of immigrants in Nigeria according to UNDESA (2010) is 1, 127, 668. This is about 0.7 percent of 173,6 million population of Nigeria (IOM-Nigeria, 2014). These immigrants came from both African and non-African countries.Table 3 shows exclusively West Africa migrants residing in Nigeria from 1975-2013. 
International Journal of Trend in Scientific Research and Development (IJTSRD) ISSN: 2456-6470

Table 5 Estimate of West African migrants living in Nigeria, 1970-2013

\begin{tabular}{|c|c|c|c|c|c|c|c|}
\hline Country & $\mathbf{1 9 7 0}$ & $\mathbf{1 9 7 5}$ & $\mathbf{1 9 8 0}$ & $\mathbf{1 9 8 4}$ & $\mathbf{1 9 9 1}$ & $\mathbf{2 0 1 0}$ & $\mathbf{2 0 1 3}$ \\
\hline Ghana & 129,872 & 312,904 & 511,859 & 680,384 & 78,706 & 158,987 & 176,493 \\
\hline Mali & 85,003 & 92,136 & 87,221 & 112,970 & 56,471 & 114,071 & 126,631 \\
\hline Gambia & 30,600 & 38,979 & 49,680 & 52,134 & 2,754 & 5,563 & 6,176 \\
\hline Sierra Leone & 28,000 & 29,112 & 38,190 & 43,458 & 1,623 & 3,279 & 3,640 \\
\hline Togo & 19,021 & 26,989 & 25,908 & 29,003 & 48,993 & 98,965 & 109,862 \\
\hline Benin & 9,981 & 15,767 & 27,103 & 29,979 & 100,939 & 203,898 & 226,349 \\
\hline Cote d' Ivoire & 3,879 & 5,721 & 8,931 & 10,432 & 1,845 & 3,728 & 4,138 \\
\hline Burkina Faso & 45,890 & 52,732 & 65,579 & 72,328 & 3,515 & 7,101 & 7,883 \\
\hline Liberia & 6,980 & 5,789 & 6,998 & 8,547 & 8,175 & 16,512 & 18,330 \\
\hline Senegal & 2,542 & 3,381 & 3,920 & 5,468 & 2,009 & 4,058 & 4,505 \\
\hline Total & 361,768 & 584,030 & 825,389 & $1,044,703$ & 305,030 & 616,162 & 684,007 \\
\hline
\end{tabular}

Source: Arthur (1991); UNDESA (2014); SIHMA (2014)

It is not out of place that just as Nigerians migrate to other countries of the world, people from other part of the world also immigrate to Nigeria. Many citizens of countries in West Africa have settled in Nigeria in the quest for security and economic reasons. Often times this influx of labour compete with indigenous labour. Just as Nigerians in Diaspora remit money to Nigeria so also do these immigrants. From 1980s to 2013 Nigeria has witnessed great inflow of immigrants. This can be attributed to the relative better living standard and tranquility obtainable in Nigeria then and low crime rate unlike the way it is now. The population of immigrant shave contributed to the pressure on the facilities in Nigeria. Nigeria has on different periods accepted to play brotherhood roles by supporting and assisting neighboring countries in crisis. The openness of boarders to West African states made easy movement of labour within the region. It can be inferred that given the population of Nigeria in relation to the other West African countries, the number of Nigerians in West African countries far outweigh the total immigrants from West Africa. A question worthy of asking is that the vacuum created by Nigerian migrants, is it covered by immigrants? Well, it is difficult to say yes or no except when having handy facts and figures. It is difficult to have same quality of immigrant labour commensurate and compensatory to migrant ones that have left Nigeria at the period under consideration.

From the foregoing, it is quite obvious that a good proportion of the Nigerian citizens are resident outside Nigeria. This presupposes that there are some factors strongly pushing people at all times to seek for good living environment and working condition outside the country. Disgustingly is the fact that many
Nigerian leaders frequently travel in those countries resident by Nigerian migrants and cherish the place but unable or unwilling to introduce those things that make those places desirable into Nigeria. Sadly to note is that some of our leaders derive joy in engaging in selfish emulative consumption from other counties but yet to adopt emulative economic restructuring and transformation capable of alleviating poverty. In addition, it is boggling and disheartening that none of the leaders have been able to reduce or tackle poverty to an insignificant level in spite of all beautiful programmes, policies and strategies put in place, instead situations prevail that perpetuate poverty in the country.

\section{An over-view of the effects of remittance}

Many scholar have the conviction that migration gives rise to inflow of resources into a domestic economy of a migrant, which is referred to as positive effect of migration while others pinpointed the opposing view of the denial of the migrants' home economy of the scarce capital resources needed for development. For instance, World Bank (2008) points out that in subSaharan Africa, a total migrants' remittance of $\$ 10.8$ billion which is $1.6 \%$ of gross domestic product was made in 2007.Ajaiyi et al (2009), in their study of 38 Sub-Saran African countries asserted that international remittances have played desirable roles in raising living standard of the people.

Mbuto (2010) posits that in Nigeria, total remittances experienced average growth of $121 \%$ from 2004 to 2006 and at the same period, the average contribution of remittances to gross domestic product was about six time higher when compared to all export income excluding that of oil. Ighomwenghian (2017) reported that remittances to Nigeria in 2016 stood at $\$ 19$ 
billion placing Nigeria as one of the top six receivers for the period although below last year remittance of $\$ 21$ billion. The fall in remittance was attributed to fall in oil prices which led to tighter capital controls and government managed exchange rate policy that gave room for black marketers' premiums in foreign exchange markets. Consequently, a large proportion of formal remittance went into informal hands. It was equally noted that remittances in developing countries fell again which has not happened for about 30 years period and as such many remittance-receiving developing countries experienced sharp fall. In Africa, Nigeria is rated highest in the contribution of remittance as a percentage of GDP of $19 \%$ in 2016. However, in this section; it is our intention to examine remittance into Nigeria with a view to take proper stand of effects of migrant remittance on Nigeria.

Surprisingly, in spite of these inflow. Poverty in Nigeria has not fallen as poverty is estimated at $70 \%$ in Nigeria. It implies that the proportions of Nigerians that benefit from remittances are insignificant proportion of the population.

Table 6 Showing outflow and inflow of remittances (in US \$million) 2009-2011

\begin{tabular}{|l|l|l|}
\hline Year & $\begin{array}{l}\text { Outflow (in US } \\
\text { \$ million) }\end{array}$ & $\begin{array}{l}\text { Inflow } \\
\text { remittances } \\
\text { US \$ million }\end{array}$ \\
\hline $\mathbf{2 0 0 9}$ & 47 & 9,585 \\
\hline $\mathbf{2 0 1 0}$ & 48 & 10,045 \\
\hline $\mathbf{2 0 1 1}$ & - & 10,681 \\
\hline Total & 95 & 30,311 \\
\hline
\end{tabular}

Source: World Bank (2014)

Remittances inflow and outflow in Nigeria cannot be ignored in view of the large number of immigrants in Nigeria and a good proportion of Nigerian migrants all over the world. The data above show that outflow of remittance far outweigh inflow. This is clear and can be attributed to dominant explorers of Nigeria oil to be expatriates and also many Nigerian students in other countries are sustained from Nigeria. This is not a very healthy situation for Nigeria who supposed to improve and equip its tertiary institutions but would prefer patronage of foreign schools at the expense of domestic institutions.
Table 7 Showing personal remittances received in Nigeria as percent of gross domestic product (GDP), real GDP and exchange rate 2000-2015

\begin{tabular}{|l|l|l|l|}
\hline Year & $\begin{array}{l}\text { Real GDP } \\
\text { (A) }\end{array}$ & $\begin{array}{l}\text { Remittances } \\
\%\end{array}$ & $\begin{array}{l}\text { Exchange } \\
\text { Rate }\end{array}$ \\
\hline $\mathbf{2 0 0 0}$ & 412,332 & 3.001 & 102.11 \\
\hline $\mathbf{2 0 0 1}$ & $431,783.2$ & 2.643 & 111.94 \\
\hline $\mathbf{2 0 0 2}$ & $451,785.7$ & 2.045 & 120.97 \\
\hline $\mathbf{2 0 0 3}$ & $495,007.2$ & 1.571 & 129.36 \\
\hline $\mathbf{2 0 0 4}$ & 527,576 & 2.587 & 133.5 \\
\hline $\mathbf{2 0 0 5}$ & $561,931.4$ & 13.043 & 132.15 \\
\hline $\mathbf{2 0 0 6}$ & $595,821.6$ & 11.643 & 128.65 \\
\hline $\mathbf{2 0 0 7}$ & $634,251.1$ & 10.823 & 117.96 \\
\hline $\mathbf{2 0 0 8}$ & $672,202.6$ & 9.229 & 130.75 \\
\hline $\mathbf{2 0 0 9}$ & 718977.3 & 10.838 & 158.5 \\
\hline $\mathbf{2 0 1 0}$ & 776332.2 & 5.35 & 153.13 \\
\hline $\mathbf{2 0 1 1}$ & $834,000.8$ & 5.007 & 158.27 \\
\hline $\mathbf{2 0 1 2}$ & 888,893 & 4.457 & 157.36 \\
\hline $\mathbf{2 0 1 3}$ & $63,218,720$ & 4.039 & 167.38 \\
\hline $\mathbf{2 0 1 4}$ & $67,152,790$ & 3.664 & 169.68 \\
\hline $\mathbf{2 0 1 5}$ & $69,023,930$ & 4.378 & 197 \\
\hline $\begin{array}{l}\text { Source: } \\
\text { https/dataworldbank.org/indicator/BX.TRF.PWKR.D }\end{array}$ \\
\hline T.GD25/location & & \\
\hline
\end{tabular}

The data above show the extent remittances have contributed to the GDP over the years. The period 2003 to 2009 excluding 2008 showed a two digit percentage contribution. The fluctuation is related to the exchange rate and the economic situation prevalent in the country at the period. It can be inferred that remittances have been impacting on Nigeria economy to an extent given the fact that exports of some none oil products have not contributed up to the amount of remittances. But it can equally be pointed out that the impact of all the professional Nigerians in Diaspora functioning in Nigeria would have impacted more on the economy than the remittances effect. Disgustingly is that the outflow or remittances from immigrants in Nigeria far outweigh what comes into Nigeria as shown by table 6. This is because some of the functional manufacturing and services provider businesses and some high level manpower are migrants in Nigerians.

\section{Implications from the two effects}

From the data on Nigerian migrants in other countries, migrants in Nigeria from other countries and out flow and inflow of remittances, it is unequivocal that migration has greater influence in Nigeria economy. Capital is really one of the major obstacles of 
development of a developing economy such as Nigeria. Just as Nigerians in Diaspora remit cash to families, relations and friends, so also do nonNigerians in Nigeria do. The data in table 6 showed that more remittance leave Nigeria than it flows. The movement of both large quality human and physical capital outside Nigeria is a thing of worry.The colossal loss of academics, educationists, doctors, lawyers, engineers, economists, entrepreneurs and other professionals through migration presupposes that remittance is not sufficient to compensate for it. The decline in quality of Nigerian graduates can be attributed apart from lack of learning facilities, but to brain-drain or migration. Although the remittances contribution to GDP is meaningful, in our perception from all the aforementioned facts and figures, it is less meaningful than what leaves the economy.

\section{Way forward}

Notwithstanding remittances contribution to Nigerian economy, it is our stance that Nigeria has to do something to minimize frequent loss of scarce capital resources (human and physical) through migration. This on the ground that the negative effect of migration in our perception outweigh the positive effects, and also given the fact that remittances do not add to public revenue or support public expenditure. But taxes of individuals and businesses impact on the public revenue which in turn affect developmental expenditure. In order to reduce all form of migration in Nigeria, the following is expected to play enormous role:

i. Revamping both the rural and urban environment, reforming social amenities and upgrading and maintenance of infrastructural requirement of the society to ensure sufficient and timely distribution of resources in the country. The unevenness of development of the rural area vis-à-vis urban areas can be altered through sufficient attention to making life conducive and promoting more investment and production in the rural areas of the country.

ii. (ii)Insecurity and frequent crisis such as group agitations, religious disharmony, crimes, Boko Haram insurgence among others must be addressed. Many Nigerians have resorted to migration to various parts of the country and outside the country as a result of internal crisis. This requires more attention be focused on harmonious co-existence of all and sundry, and intensification of protection of all lives and property. iii. Condition of service for all categories of workers both the local, state and federal need to be urgently harmonized. Inequality in income of people with similar qualification and skill serving at different tiers of the government should be put to an end. Good atmosphere for operation cum the materials required by the academics, doctors, nurses, lawyers, architects, economists among others to enable them put in their best must be provided. This implies annihilation of brain-drain and improving reward system commensurate to input. It equal calls for reducing cost of governance to enable more funds to be available to restructure the economy for better.

iv. Institutions of learning and health centres must be properly staffed and equipped. Nigeria has to practically and conscientiously emulate or adopt pattern of education system, management of students and staff as it is obtainable in Japan, United Kingdom, United States among others. The colossal sum of hard currency spent by Nigerians in the pursuit of education and health care outside Nigeria is enough to reform Nigerian education system for effective knowledge impartation and service delivery.

v. Nigeria should work frantically to industrialise so as to reduce over reliance on exportation of raw materials so as to increase aggregate economic activity and bring about more employment of resources.

vi. Good governance is essential at the moment such as strict adherence of the rule of law, freedom of speech, freedom of association avoidance of nepotism, equitable distribution of societal resources, giving all the opportunity to be part of leadership and strict compliance with respect to federal character in all facets of the economy.

\section{CONCLUSION}

This paper has examined and reviewed the effects of migration and remittances in Nigeria over the years. It was obvious that remittances from migrants have tremendously impacted on the Nigerian economy but it was perceived to be below the impact the Nigerians in Diaspora would have, have supposing the working environment was conducive for them to remain and work in Nigeria. This view is supported by the perception of the Deputy Executive-Secretary of the Economic Commission for Africa who posits that the exodus of African experts to the West is one of the 
greatest barriers to Africa's progress and that African leaders have a major obligation to ensure that professional remain in the continent; or else, in 25 years' time, Africa will be empty of brains (Sivia, 2007; Thalasa, 2010). It is the stance of the authors that more development and better living standard is possible in Nigeria if the abundance human capital outside the country are made to stay and contribute their quota to aggregate economic activity through revamping and restructuring the economy for better economic activities that can provide good working environment and give job opportunities to the teeming unemployed.

\section{REFERENCES}

1) Ajayi, M.A., Ijaiya, M. A, Bello, R. A.,Ijaiya, G. T \&Adeyemi, S. L (2009).International Remittances and Well-Being in Sub-Saharan Africa.\| Journal of Economics and International Finance, 1(3), 78-84.

2) Anyanwu, J. C., \&Erhijakpor, E. O. (2010).Do Remittances Affect Poverty in Africa?\|African Development Review, 22(1), 51-91.

3) Adams, R.H., \& Page, J. (2005).Do International Migration and Remittances Reduce Poverty in Developing Countries? World Development, 33(10), 1645-1669

4) Arthur, J.A. (1991). International Labor Migration Patterns in West Africa. African Studies

Review 34(3).

5) Azam, J.P., \&Gubert, F (2006).Migrants' Remittances and the Household in Africa: A Review of the Evidence.\|l Journal of African Eco, AERC Supplement 2, (15), 426-462.

6) Barajas, A., Chami, R, Fullenkamp, C, Gapen, M \&Montiel, P (2009).Do Workers' Remittances Promote Economic Growth?\| IMF Working Paper WP/09/153, International Monetary Fund, Washington DC.

7) Central Bank of Nigeria (1998) Statistical Bulletin, 9(1), Abuja, CBN.

8) Central Bank of Nigeria ( 2015) Statistical Bulletin, Abuja, CBN

9) Chami, R., Hakura, D, \&Montiel, P. (2009). Remittances: An Automatic Output Stabilizer? ॥IMF Working Paper WP/09/91, IMF.

10) El-Sakka, M. I. T. and McNabb, R. (1999) "The Macroeconomic Determinants of Emigrant Remittances", World Development, Vol.27, No.8, pp.1493-1502.
11) Funk, M, Namara, F. M, Pardo, R, \& Rose, N (2017).Tackling Irregular Migration through Development - a Flawed Approach? European Policy Centre

12) upta, S., Pattillo, C \&Wagh, S. (2007). Impact of Remittances on Poverty and Financial Development in Sub-Saharan Africa. IMF Working Paper, WP-07-38, IMF.

13) Hughes, M and Kroechler, C. J (2008). Sociology the Core, 8th edn. New York: McGraw Hill Higher Education.

14) Higgins, M. L. Hysenbegasi, A and Pozo, S. (2004) "Exchange-Rate Uncertainty and

Workers' remittances", Applied Financial Economics, Vol.14, pp.403-411.

15) International Organisation for Migration (2013). 'Assessment of Migration Data Management and IT Capacities in Nigeria Terms of Reference.' Retrieved on July 22, 2013 from www.acpmigration-

obs.org/.../TOR_Migration\%20 Data\% 20Assessment.

16) IOM-Nigeria (2014). Facts and Figures. Retrieved on Sept 19, 2017 from https://www.iom.int/ $\mathrm{cms} / \mathrm{en} / \mathrm{sites} /$ iom/home/where-we-work/africaand-the-middle-east/central- and-westafrica/nigeria.html

17) Ighomwenghian, K (2017). Nigeria Receives $\$ 19$ billion Remittances in 2016-Report, retrieved on September, 2017 fro http;//invesdata.com.ng/2017/04/Nigeria received -19bn remittances 2016 report

18) Kartz, E. (2000), 'Social Capital and Natural Capital: A Comparative Analysis of

Land Tenure and Natural Resources Management in Guatamala,' Land Economics, 76(1)

19) Knoll, A, \& Sherriff, A (2017).Making Waves: Implications of the irregular migration and refugee situation on Official Development Assistance spending and practices in Europe, Retrieved from www.eba.se on July 28, 2017

20) Lachaud, J.P. (1999). Pauvrete, Ménages et Genre enAfrique Sub-saharienne. Serie de recherché 03, Centre d'Economie du Developement de l'Universite Montesquieu Bordeaux IV.

21) Lucas, R. E. B. and Stark, O. (1985) "Motivations to Remit: Evidence from Botswana", 
Journal of Political Economy, Vol.93, No.5, pp.901-918.

22) Mbuto, O. M (2010). Can Monetary Policy Enhance Remittances For Economic Growth in Africa? The Case of Nigeria. Journal of Economics and International Finance, 2(8), 156163 ,

23) Mohapatra, S, Ratha, D, and Scheja, E (2010). Impact of Migration on Economic and Social Development: A review of evidence and emerging issues. Migration and Remittances Unit, World Bank, for the Civil Society Days of the Global Forum on Migration and Development 2010.

24) National Bureau of Statistics (2010) Nigeria Poverty Profile, Abuja, NBS.

Nwosu, O. E, Fonta, M. W, Aneke, G \&Yuni, N. D (2012). Microeconomic Determinants of Migrant Remittances to Nigerian Households, Economic Bulletin, 32(4), 3425-3438

25) Rena, R (2008). 'Brain Drain and Brain Gain in Africa,' Study Mode.com. Retrieved on June 3, 2013 from http://www.africaeconomicanalysis.org /articles/69/1/ Brain-Drain-And-Brain-Gain-InAfrica/Page1.html

26) Scalabrini Institute for Human Mobility in Africa (SIHMA, 2014). Migration Profile: Nigeria, SIHMA, South Africa

27) Singh, R.J., Haacker, M, \& Lee, K. W. (2009). Determinants and Macroeconomic Impact of Remittances in Sub-Saharan Africa. IMF Working Paper WP/09/216, IMF.

28) Spatafora, N. (2005).Two Current Issues Facing Developing Countries.l Chapter in World Economic Outlook, International Monetary Fund (IMF).

29) Straubhaar, T. (1986) "The Determinants of Workers' Remittances: The Case of Turkey, WeltwirtschaftlArchiv, Vol.122, No.4, pp.728-40.

30) Silvia, C B. (2007). 'Brain Drain in Africa Migration in the Health Sector'. StudyMode.com. Retrieved June 3, 2013 from http://www.studymode.com/essays/Brain-DrainAfrica-Migration-Health-123395.html

31) Thalasa, B. A (2010). 'Brain Drain'. StudyMode.com. Retrieved June 3, 2013 from http://www.studymode.com/essays/ Brain-Drain452987.html.
32) Toxopeus, H., and Lensink, R (2007).Remittances and Financial Inclusion in Development.\| $U N U$ WIDER Research Paper, Vol. 2007/49, Helsinki.

33) Uma, K,E, Eboh, F.E \&Obidike, P.C (2013).Managing rural-urban migration and brain drain for sustainable economic recovery in Nigeria: Constraints and options, Journal of Economics and International Business Management, 1(1), 1-8

34) United Nations High Commissioner for Refugees (UNHCR) (2009). Statistical Online Population Database, UNHCR, Geneva.

35) UNDESA (2014).“Trend in International Migrants Stock: The 2013 Revision" Population Division UNDSA, Geneva.

36) United Nations. (2009).International Migrant Stock: The 2008 Revision.ll United Nations Population Division (http://esa.un.org)

37) United Nations High Commissioner for Refugees (UNHCR) (2009). Statistical Online Population Database, UNHCR, Geneva.

38) UNHCR (2014a).Statistical Online Population Database. http:/www.unhcr.org/pages/4a013eb06.html.

39) UN Department of Economic and Social Affairs (2012)

40) UN Department of Economic and Social Affairs (2015). International Migration Wallchart 2015.

41) World Bank (2006). Global Economic Prospects 2006: Economic Implications of Remittances and Migration. World Bank, Washington DC

42) World Bank (2008). Migration and Remittances Fact Book 2008. Washington D.C: The World Bank

43) World Bank (2011). Migration and Remittances Factbook 2011 Washington, D. C. 